Published in Chemosphere, v. 39, pp. 229-246 (1999) (C) Elsevier Science Bv.

\title{
ROLE OF DESERT AEROSOL IN METAL FLUXES IN THE MEDITERRANEAN AREA
}

\author{
S. GUERZONI ${ }^{1,3}$, E. MOLINAROLI ${ }^{2}$, P. ROSSINI $^{1}$, G. RAMPAZZO $^{2}$ \\ G. QUARANTOTTO ${ }^{1}$, G. DE FALCO ${ }^{3}$ and S. CRISTINI ${ }^{4}$
}

(1) Consiglio Nazionale delle Ricerche, Istituto di Geologia Marina, via Gobetti 101, 40127 Bologna, Italy

(2) Università di Venezia, Dipartimento di Scienze Ambientali, Dorsoduro 2137, 30123 Venezia, Italy

(3) International Marine Centre, Loc. Sa Mardini, 09072 Torregrande (OR), Italy

(4) Università di Cagliari, Dipartimento di Scienze della Terra, via Trentino, 51, 09127 Cagliari, Italy

\begin{abstract}
(220 parole)
Aerosols and precipitations collected over Sardinia are mainly controlled by two endmembers: Saharan and European. European background aerosols in Sardinia show a 3 to 25-fold decrease in $\mathrm{EF}_{\text {crust }}$ values for $\mathrm{Cd}, \mathrm{Zn}, \mathrm{Pb}$, and $\mathrm{Cr}$ compared with coastal stations in the Western Mediterranean. Partitioning of total atmospheric deposition between the soluble and the insoluble phases shows that $\mathrm{Al}, \mathrm{Si}, \mathrm{Fe}$ and $\mathrm{Pb}$ originating from the atmosphere are mostly in the insoluble form. For $\mathrm{Ca}, \mathrm{Cd}, \mathrm{Cr}$ metals the dissolved fraction represents $50-90 \%$ of the total input.

Aerosol dissolution experiments performed at particle concentrations ranging from 3 to $300 \mathrm{mg}^{-1}$ show $\mathrm{Cd}$ and $\mathrm{Pb}$ exhibiting low solubility at the high mass particle concentration. Solubility of $\mathrm{Pb}$ increases with the $\mathrm{EF}_{\text {crust }}$ values and the finest grain-size of the aerosols $(<1 \mu \mathrm{m})$, and is less affected by $\mathrm{pH}$. $\mathrm{Al}$ and Fe solubilities appear to be mainly controlled by the particulate load. Dissolution of both metals decreases significantly from $30 \%$ (13\% for $\mathrm{Fe}$ ) at aerosol loads lower than $5 \mathrm{mg} \mathrm{l}^{-1}$, to less than $1 \%$ for both metals, at total aerosol concentrations greater than $50 \mathrm{mg} \mathrm{l}^{-1}$, which are encountered during Saharan transport.

Fluxes (dry +wet) of metals at Sardinia show that $\cong 30 \%$ for $\mathrm{Cd}$ and $\mathrm{Pb}$, to more than $80 \%$ for $\mathrm{Fe}$ and $\mathrm{Al}$ are due to Saharan contribution.
\end{abstract}




\section{INTRODUCTION}

There is increasing recognition that the atmosphere can be an effective, and in some cases dominant, transport path for pollutants entering the coastal and ocean (Duce et al., 1991(1). Trace metals are emitted by industries activity from populated areas around the Mediterranean (MED) basin and from the north part of Europe (European background=BKG). In addition, with seasonal character, "pulses" of Saharan (SAH) dust carry large amounts of metals of natural origin to the MED and adjacent continental regions. The two sources are chemically very different, in particular with respect to their trace metal content. The metals attached to the aerosols can reach the sea surface following different pathways: (i) by dry deposition in which aerosols are delivered directly to the sea surface by air-sea route and trace metal solubility is constrained by aerosol-sea water reactions; (ii) by wet deposition in which aerosols reach the sea surface by the indirect air-rain water-sea water route, following in-cloud or below-cloud precipitation scavenging processes.

Several authors (Guerzoni et al., 1997(2); Loye-Pilot \& Martin, 1996 (3); Bergametti et al., 1989(4) concluded that the two major factor controlling variations in particulate trace metal concentrations in the western MED are: (i) precipitation scavenging which affects both crustal and anthropogenic trace metals; and (ii) the inputs of SAH dusts, which affects crustal trace metals.

Global estimates of dust deposition to the MED Sea range significantly from 25 to $100 \mathrm{Tg} \mathrm{yr}^{-1}$ (D'Almeida, 1986 (5); Prospero, 1996 (6). Much of the variation results from the difficulty in obtaining good estimates of dust deposition. Despite the shortcomings in these estimates, it is shown for many metals (e.g., $\mathrm{Al}, \mathrm{Pb}, \mathrm{Mn}, \mathrm{Fe}$ ) that the global flux from the partial dissolution of eolian dust in surface waters is much greater than that carried by Rhone and Po rivers for Western MED and Adriatic Sea respectively (Guieu et al., 1997 (7); Rossini and Guerzoni, 1996 (8). In the open seas, atmospheric input may be therefore the only source of bioavailable metals to the marine system, and those metals can play an important role in the marine biological productivity (Duce and Tindale, 1991 (9); Young et al., 1991 (10). In recent years several authors have studied the trace metal dry, wet and/or total deposition in the Western MED (Dulac et al., 1989 (11); Remoudaki et al., 1991 (12); Migon et al., 1991 (13), 1997 (14) and a very large data set obtained during the EROS 2000 project has permitted to establish a reliable dissolved/particulate input budget to the NW MED (Guieu et al (1997 (7).

There has been considerable debate as to metal solubility estimates (Jickells, 1995 (15) although a reasonable consensus on the range of solubilities observed for environmentally important metals in rainwater has now been reached (Losno et al., 1993 (16); Lim et al., 1994 (17); Spokes et al., 1994 (18). Previous studies have also emphasised the importance of $\mathrm{pH}$ and aerosol type in controlling aerosol dissolution (Chester et al., 1993a (19); Lim et al., 1994 (17); Spokes et al., 1994 (18). This study aims to (i) identify how concentration, mineralogy, grain size and chemistry of the insoluble fraction control aerosols metal partitioning solid and solution phases, and to (ii) estimate the importance of desert dust in the atmospheric trace metal input. 


\section{SAMPLING AND ANALITICAL METHODS}

\section{Sampling}

Chemical data of the soluble and insoluble fraction of aerosols collected at a land-based coastal station in SE Sardinia, Western MED ( $9^{\circ}$ long E, $39^{\circ}$ lat N) (Fig. 1) are presented. A total 88 samples (55 aerosol; 33 rain) were collected during the period October 1990/April 1992 and presented here. Aerosol samples were collected with high volume $\left(60 \mathrm{~m}^{3} \mathrm{~h}^{-1}\right)$ Sierra Andersen ${ }^{\odot}$ sampler, using filters made of polyester as well as Whatman 41 filters. Sampling time was 72 hours. A detailed description of sampling site and characteristics of the aerosols can be found in Guerzoni et al. (1997) (2). Three separate quarters of the filters were then used for three separate analyses: (i) acid digestion for total trace metal analyses; (ii) water extraction for major anions; (iii) leaching experiment for dissolved trace metal analyses. Filter chemical blanks were determined from filters that were taken into the field and handled in the same manner as those used for sample collection.

Rain samples were collected using a Wet \& Dry (ARS 200 MTX $^{\odot}$ ) automatic collector, and the sample is filtered through a $0.2 \mu \mathrm{m}$ diameter Nuclepore $^{\odot}$ polycarbonate preweighted filter within few hours, and subdivided into two phase fractions, soluble and insoluble. The insoluble fraction was dried in a dry-box and re-weighted (to obtain the total particulate concentration). Blanks were run periodically, by making all operations with only Milli- $\mathrm{Q}^{\mathrm{TM}}$ water instead of samples. Filtering was done with a Millipore ${ }^{(}$ Sterifil unit, equipped with a pre-filter on the cover, to avoid contamination with ambient air. The analyses of the filtrate and residual fraction on filters defined the dissolved and particulate metal concentrations.

All manipulations were conducted in clean rooms equipped with a laminar flow hood.

\section{Trace metal dissolution experiments}

The laboratory leaching experiments were designed for the extraction of the water soluble components of the particles collected on filters.

In the experimental procedure portion of filters (one quarter) on which aerosol had been collected were folded and placed in acid-cleaned Teflon bottles $(250 \mathrm{ml})$. We used different particulate amounts, choosing from our filter library appropriate concentration of particulates onto the filter for each sample. The particulate concentrations were known by separately weighthing another portion of the filter. Filters were leached with $100 \mathrm{ml}$ of ultrapure deionised water (Milli- $\mathrm{Q}^{\mathrm{TM}}$ ), on a reciprocating shaker at high speed for one hour. Then the filters were removed and the solutions were filtered through a 0.2 $\square \mathrm{m}$ Nuclepore $\odot$ polycarbonate filter, and the metals recovered in the filtrate were operationally considered as being dissolved. Dissolution in rain water and sea water of metals attached to aerosols occurs in short time (Statham and Chester, 1988 (20); Guieu et al. 1994 (21) therefore, we assumed that the exposure time chosen for this experiment allows to simulate the natural conditions. The dissolution experiments were performed at particle concentrations ranging from $\approx 3$ to $\approx 300 \mathrm{mg} \mathrm{l}^{-1}$, at an initial $\mathrm{pH}$ of the Milli$\mathrm{Q}^{\mathrm{TM}}$ water of 5.0-5.5. After filtration, the solution $\mathrm{pH}$ was measured and the filtrate was then acidified to $\mathrm{pH} 2$. The $\mathrm{pH}$ of the added water was always roughly the same so the final $\mathrm{pH}$, after leaching, was altered by aerosol itself, thus obtaining the range of 
experimental $\mathrm{pH}$ values. The solutions were then anlysed for trace metals using flame and flameless atomic absorption techniques, as appropriate.

\section{Trace metal analysis}

Another quarter of the aerosol filter was digested following dissolution in $\mathrm{HNO}_{3} / \mathrm{HF}$ in teflon bombs. Trace metal concentrations were determined by graphite furnace atomic absorption spectrophotometry (GFAAS). Sampling methods, sample treatment and analytical methods are described in detail in Guerzoni et al. (1993 (22); 1997 (2) and Molinaroli et al. (1993) (23).

To determine the precision and the accuracy of trace metal analyses by GFAAS, certified standard solutions were regularly analyzed throught the period of study. Results showed that analytical accuracy was of the order of $\pm 5 \%$, and precision was of the order of \pm 5 and $10 \%$ based on analysis of replicate samples and both solid and aqueous standards. Detection limits (DL), defined as three times the standard deviation of the blank, were calculated from replicated analysis of ultrapure deionised water (Milli- $\mathrm{Q}^{\mathrm{TM}}$ ) at $\mathrm{pH}$ 5.6, the matrix used in the experiment. For the elements of interest, DL values were: $\mathrm{Al}$ and Si $0.5 \square \mathrm{g} \mathrm{l}^{-1}$, Cd $0.04 \square \mathrm{g} \mathrm{l}^{-1}$; Ca, Cr, Cu and Fe $1 \square \mathrm{g} \mathrm{l}^{-1} ; \mathrm{Pb} 0.4 \square \mathrm{g} \mathrm{l}^{-1}$.

\section{Determination of blanks}

Operational field blanks were performed using precipitation and aerosol sampling protocols at sampling sites by deploying and momentarily exposing "clean" rain collectors and filters between precipitation and aerosol sampling events. Blank concentrations of dissolved $\mathrm{Al}, \mathrm{Fe}, \mathrm{Cd}$ and $\mathrm{Pb}$ ranged between \pm 5 and $10 \%$ trace metal concentrations in the precipitation analysed. For particulate trace metals, clean filters were taken through the in $\mathrm{HNO}_{3} / \mathrm{HF}$ digestion, and the resulting blank solution were anlysed. As a percentage of trace metal concetration in particulates, filter blanks were as follows: $\mathrm{Al}, \mathrm{Ca}, \mathrm{Fe}, \mathrm{Mg}, \mathrm{Si}, \pm 5$; $\mathrm{Cr}, \mathrm{Pb}, \mathrm{Zn} \pm 10 \%$; $\mathrm{Cd}, \pm 12 \%$. All trace metal concentrations reported here are blank corrected

\section{RESULTS AND DISCUSSION}

\section{Measurement in air and rain}

The atmosphere is a very dynamic compartment of the earth system and the concentrations of reactive gases and particulate matter are highly variable in space and time. This variability ranges from rapid day to day changes in aerosol lead concentration as a result of changes in atmospheric transport and removal (Fig. 2a), to massive changes in dust loadings over Sardinia, a result of seasonal dust outbreaks in Africa (Fig. 2b). The peculiar influence of dryness on aerosol samples collected on MED islands was discussed by Bergametti et al. (1989) (4) and was also found in Sardinia, where a three-fold increase in mass loading for the samples collected with more than three rainless days was shown (Guerzoni et al., 1995) (24).

Previous work (Guerzoni et al., 1997) (2) has shown that at sites relatively far from pollution sources it is possible to de-couple the desert-derived "end-member" aerosol 
from the "BKG" component. A multiple approach can be adopted to achieve this: (i) the use of air-mass back trajectories to define source regions (Harris et al., 1982) (25); (ii) the fact that much of the SAH dust over the MED Sea is transported in the form of "pulses", and the identification of these "pulses" offers a potential way of isolating the desert-derived component; (iii) other combined criteria which could be used to classify BKG and SAH aerosols include the use of mineralogical markers (Molinaroli, 1996) (26), Al/Si ratio (Bergametti et al., 1989) (4) and Ca content (Molinaroli et al., 1993) (23). Finally, for precipitation, (iv) $\mathrm{pH}$ values were also used to improve classification, since the alkalinization effect of SAH dust in rain has been well described, both in Sardinia (Caboi et al., 1992 (27); Le Bolloch and Guerzoni, 1995 (28) and elsewhere (Löye-Pilot et al., 1986 (29); Glavas 1988 (30); Roda et al., 1993 (31).

The SAH outbreaks in our data set represent less than $15 \%$ of the total sample ( 7 out of 55) for the aerosols, and slightly more than $30 \%$ of the rainwater samples (10 over 33). The strongest episodes occurred in two periods: October-November, and MarchApril, and principally with mixed, SW and E-SE winds.

In Table 1 we have listed the particulate load and grain-size characteristics of the aerosols collected at Sardinia. The data are divided in two groups: SAH, mainly desertenriched aerosol, and BKG, mainly anthropogenic-maritime enriched aerosol. From this table it is apparent that the soluble fraction, mainly composed of sea-salts (7095\%), is similar in SAH and BKG aerosols (25 and $16 \mu \mathrm{g} \mathrm{m}^{-3}$ ), whilst the most important difference is in the insoluble (mineral) fraction, highly enriched in SAH episodes. Grain-size data also show an enrichment in fine-grained fraction $(<1 \mu \mathrm{m})$ in the BKG, as compared to coarser enrichment $(2-8 \mu \mathrm{m})$ in the $\mathrm{SAH}$ aerosols. Table 2 lists the average concentration of particulate load encountered in Sardinia during the sampling period, where a range of more than two orders of magnitude is apparent, both in aerosol and rainwater samples.

In Tables 3 and 4 the relevant metal data of aerosols and precipitation collected at Sardinia are listed together with the average crustal abundance $\left(\mathrm{EF}_{\text {crust }}\right)$, and the percentage of dissolved fraction. The data set given in the two tables provide examples of the contrasting atmospheric chemistries of the trace metals at the Sardinia site.

(i) The SAH samples have always higher values, of all the crustal elements ( $\mathrm{Al}, \mathrm{Ca}$, $\mathrm{Fe}, \mathrm{K}, \mathrm{Mg}, \mathrm{Si}$ ) than $\mathrm{BKG}$, both in aerosols and rainwater.

(ii) $\mathrm{Al}, \mathrm{Fe}$ and $\mathrm{Si}$ are mostly in the insoluble form (range of solubility 0.4-10\%), whilst $\mathrm{Ca}, \mathrm{K}$ and $\mathrm{Mg}$ are mainly (50-90\%) in the dissolved fraction.

(iii) $\mathrm{Cd}, \mathrm{Cr}$ and $\mathrm{Pb}$ have lower solubilities in aerosol as compared to rainwater, both in SAH and BKG samples.

\section{$\underline{\text { Mixture of Crustal/European aerosol (EF's) }}$}

The degree to which a trace metal in aerosol or rain water is enriched or depleted, relative to the crustal source, can be assessed by using an enrichment factor ( $\left.\mathrm{EF}_{\text {crust }}\right)$.

For crustal sources, Al, is normally used as the source indicator element and the Earth's crust as the source material (Taylor, 1964) (32). The $\mathrm{EF}_{\text {crust }}$ value is then calculated according to an equation of the type:

$$
E F_{\text {crust }}=\left(C_{x p} / C_{A l p}\right) /\left(C_{x c} / C_{A l c}\right)
$$


where $\left(C_{x p}\right.$ and $\left.C_{A l p}\right)$ are the concentrations of a trace metal $\underline{x}$ and $\underline{A l}$, respectively, in the aerosol, and $\left(C_{X C}\right.$ and $\left.C_{A l}\right)$ are their concentrations in average crustal material.

When the concentrations of trace metals in aerosols are plotted on EF diagrams the overall population can be described in terms of mixing of anthropogenic-rich components, which have high $\mathrm{EF}_{\text {crust }}$ values $\left(\mathrm{EF}_{\text {crust }}>10\right)$ for all trace metals and crustrich components, which have low $\mathrm{EF}_{\text {crust }}$ values $\left(\mathrm{EF}_{\text {crust }}<10\right)$ for all trace metals. Enrichment Factors of the Sardinia samples are reported in Tab. 3 and 4.

Previous work (Chester et al., 1993a) (19) has describedied the "chemical character" of the MED atmosphere containing both crust derived and urban derived aerosols. At landbased stations on the northern part of West MED the aerosols have European-dominated "chemical character" similar to that of other Western European aerosol population (i.e. North Sea). In contrast, aerosol from the SAH region to the South have a crust dominated "chemical character". Thus, the chemical composition of the MED particulate aerosol can be considered to be largely constrained by the extent to which "BKG" material is perturbed by mixing with desert material.

In Figure 3 our data from Sardinia are displayed on the EF diagrams together with trace metals in aerosol at two coastal sites (Blanes and Cap Ferrat) (Chester et al., 1993a) (19). For all the aerosols Fe displays low $\mathrm{EF}_{\text {crust }}$ values (Fig.3A). Therefore, the Fe is a crustdominated trace metal under all conditions in the aerosol from the MED and surrounding regions.

On the EF diagram $\mathrm{Zn}$ (Fig. 3B); and Pb (Fig. 3C) both plot in two fields One is the "mixing relationship" field, and the other is where this field is perturbed at the upper right hand corner as a result of the localised inputs of urban-rich material at the Blanes and Cap Ferrat sites. Thus, over the MED and surrounding regions inputs of crustal material are not sufficient to force $\mathrm{Zn}$ and $\mathrm{Pb}$ to behave as a crust-dominated trace metal. The Sardinia samples fall in the "mixing relationship" field; i.e. the Sardinia aerosol shows none of the "extreme" perturbations resulting from the local inputs of either anthropogenic-rich or crust-rich material such as those shown by aerosols collected at the Blanes and Cap Ferrat sites. Thus, the $\mathrm{W} \Rightarrow \mathrm{E}$ fall off in both (i) trace metal

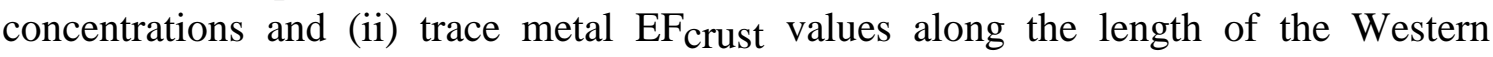
Mediterranean results, at least in part, from the input of local anthropogenic-rich material, which most strongly affects $\mathrm{Cd}, \mathrm{Zn}$ and $\mathrm{Pb}$, at the Blanes and Cap Ferrat sites; inputs which are not recorded in the aerosols collected at the Sardinia site in sufficient quantities to perturb the "mixing relationship" between crustal and anthropogenic material. In terms of its "chemical character", therefore, the Sardinia aerosol may be distinguished from those aerosols collected at the more mainland coastal sites surrounding the Western Mediterranean.

\section{Dissolution in water of metals associated to aerosols}

In order to study the role of desert particulates in the dissolution processes, we have performed a leaching experiment, concentrating on a few metals of both crustal ( $\mathrm{Al}, \mathrm{Fe})$ and anthropogenic $(\mathrm{Cd}, \mathrm{Pb})$ origin and trying to identify process which affect dissolution. The reason of this kind of study is related to the findings of Chester et al. (1993a) (19), who have shown that a perturbation in the urban/crustal aerosol ratio results in a change in the dissolved/particulate partitioning. The leaching experiment is 
also connected to the recent work of Spokes and Jickells (1996) (33), who identified additional processes related to particulate load which affect solution phase removal.

Studies of the chemical and physical properties of atmospheric particles of different areas of the world (Rahn, 1976 (34); Prospero, 1981 (35); Duce et al. 1991 (1) have allowed the following conclusions to be drawn: (i) the large particle fraction $(>1 \mu \mathrm{m}$ aerodynamic diameter) derives mostly from natural sources in arid areas of the world and is responsible for the release of $\mathrm{Al}, \mathrm{Fe}, \mathrm{Si}$ and $\mathrm{P}$ to ocean waters. (ii) Smaller particles $(<1 \mu \mathrm{m})$ are predominantly of anthropogenic origin and lead to the enrichment of elements such as $\mathrm{Pb}, \mathrm{Cu}, \mathrm{Zn}, \mathrm{Cd}, \mathrm{N}$, As and $\mathrm{Hg}$, especially in the Northern Hemisphere. (iii) Both size fractions contribute $\mathrm{Mn}, \mathrm{V}$ and $\mathrm{Cr}$ to surface waters.

Some problems arise in assessing the trace metal solubility for "dry" deposition samples, expecially from large natural particles. Using theoretical deposition velocities will give a sensible estimate of the dry deposition flux. The question is how to assess metal solubility for this flux, since dry deposition is particle-sized constrained and is more "crustal" in character than the aerosol from which is derived. Because of this, using data for the parent aerosol may considerably over-estimate the trace metal solubility in "dry" deposition.

To partially overcome this problem, Chester et al. (1993b) (36) have outlined a relationship between the $\mathrm{EF}_{\text {crust }}$ value and the seawater solubility, where $\mathrm{Cu}, \mathrm{Zn}$ and $\mathrm{Pb}$ have higher seawter solubilities in the urban-rich than in crust-rich poulation. Therefore it should be possible to correct our laboratory data by using the EF values.

\section{Leaching experiment}

We have been conducting particle/water interactions studies using aerosol concentrations, $\mathrm{pH}$ conditions and timescales representative of those in rainwater. This study used aerosols than can be considered SAH end-members (whilst not "pure" SAH dusts), as well as aerosols with an anthropogenic-dominated signature, with all the intermediate mixed samples. We decided not to adjust the $\mathrm{pH}$, in order to avoid alteration in the dissolution rates of some minerals (Maring and Duce, 1989 (37); Wieland and Stumm, 1992 (38) and to observe the effect of aerosl itself on the $\mathrm{pH}$.

We are aweare that there are several inherent difficulties in applying the results to the "real" world, in particular:

(i) the experimental system does not allow us to reproduce completely the $\mathrm{pH}$ ranges likely to be encountered by aerosols, but rather assesses wether metal solubility is affected by particle mass, grain-size, and minerals, at $\mathrm{pH}$ values higher than 5.0-5.5;

(ii) the results of the experiments can be related directly to the rain water, but it is more diffucult to extrapolate them to dissolution in sea water;

(iii) there might be a fractionation from the parent aerosol to the dry deposition, with a possible depletion of $\mathrm{Cd}$ and $\mathrm{Pb}$ in the latter one.

\section{$\underline{A l \text { and } F e}$}

Our $\mathrm{Al}$ and $\mathrm{Fe}$ solubilities are wide ranging (Al: 0.3-28\%; Fe: 01-13\%) and resulted to be mainly controlled by the particulate load. The percentage of aluminium and iron dissolution decreases significantly as particulate loading increases. Many studies have reported anomalous metal solubility behaviour dependent not only on the type of 
particle surfaces present, but also on absolute particle concentrations (e.g. Stumm, 1992 (39); Morel and Gschwend, 1987) (40). In our experimental design, aluminium dissolution decreases significantly (Fig. 4a) from more than $20 \%$ at aerosol loadings lower than $5 \mathrm{mg} \mathrm{l}^{-1}$, to less than $1 \%$, at total aerosol concentrations greater than $100 \mathrm{mg}$ $1^{-1}$, which are mass particle values usually detected during the SAH dust outbreaks. Same pattern was observed also for iron (Fig. 4b), even with much fewer samples analysed. At aerosol loadings less than $20 \mathrm{mg} \mathrm{l}^{-1}$, an average of $6 \%$ of iron present in aerosol undergoes dissolution with this value decreasing rapidly to average $1 \%$ at total aerosol concentrations greater than $200 \mathrm{mg} \mathrm{l}^{-1}$. In the case of iron, our results are in agreement with the findings of Spokes and Jickells (1996) (33). Those authors added varying amounts of Saharan aerosols (up to a particulate load of $140 \mathrm{mg} \mathrm{l}^{-1}$ ) and showed that the percentage iron dissolution deacreased significantly as particulate loading increased, altough apparently not under solubility control. On the other hand, the same authors (33) showed a linear relationship of dissolved manganese and aluminium with particulate loading, with no evidence that the dissolution was under solubility control.

Our dissolved $\mathrm{Al}$ data showed a non linear increase in solution concentration with particulate load (Fig.4c) and the reason of the percentage aluminium dissolution decrese (Fig. 4a) with increasing particulate load is unclear but may result from:

(i) aerosols acting as adsorption substrates, at high particulate loadings, with the resultant removal of dissolved metals from seawater (36), rather than providing a source through desorption;

(ii) increased solid aggregation with increasing particulate load leading to a net decrease in the number of $\mathrm{Al}$ desortpion sites (33);

(ii) partial formation of Al hydroxide compounds. Losno et al (1993) (16) have shown that at $\mathrm{pH}>5$, which are our experimental conditions, the precipitation of $\mathrm{Al}$ hydroxide compounds (e.g. $\mathrm{Al}(\mathrm{OH})_{3}$, gibbsite) or a trivalent basic insoluble $\mathrm{Al}$ salt is likely.

Results for Al are in contrast with Wieland and Stumm (1992) (38) who show that aluminium dissolution from kaolinite, which represents $20-30 \%$ of the total clay mineral of SAH samples (Molinaroli, 1996) (26), increases linearly with suspended load.

We have calculated Kd values for Al using the formulation of Hydes and Kremling (1993) (41):

$$
C_{d}=\frac{f[S]}{\left(1+K_{d} S\right)}
$$

where: $\mathrm{Cd}=$ dissolved metal concentration $\left(\mathrm{g} \mathrm{ml}^{-1}\right) ; \mathrm{F}(\mathrm{S})=$ geochemically available metal in solid $\left(\mathrm{g} \mathrm{ml}^{-1}\right) ; \mathrm{Kd}=$ distribution coefficient $\left(\mathrm{ml} \mathrm{g}^{-1}\right) ; \mathrm{S}=$ particulate load $\left(\mathrm{g} \mathrm{ml}^{-1}\right)$ to predict dissolved metal concentrations given a knowledge of particulate load.

Calculated Kd values were not constant, and range from $2 \times 10^{5}$ to $6 \times 10^{6}$ (assuming all the aluminium in the aerosol is available for dissolution), showing some anomalous particle concentration effect. The higher $\mathrm{Kd}$ values were at $\mathrm{S}<25 \mathrm{mg} \mathrm{l}^{-1}$ with some decrease with increasing to $\mathrm{S}>100 \mathrm{mg} \mathrm{l}^{-1}$, probably due to colloids (Honeyman and Santchi, 1988 (42). It was impossible to fit the data from this study to the Hydes and 
Kremling equation, at any single Kd value, and we could not try to fit the data by using a more appropriate fraction (e.g. loosley bound) since we did not performe any solid state speciation experiment on this aerosols (36).

Further experiments are needed, in order also to check the role of previously weathered primary minerals (Giusti et al., 1993) (43), and of the grain-size of the particles on the particle load control on aluminium solubility.

\section{$\underline{P b \text { and } C d}$}

Previous work has shown that at Sardinia $\mathrm{Cd}$ and $\mathrm{Pb}$ are of predominantly anthropogenic origin. In Figure 5 the dissolved fraction of $\mathrm{Cd}$ and $\mathrm{Pb}$ is plotted versus the particulate load. Solubilities of the two metals are also quite different. Solubility for $\mathrm{Pb}$ range from $\approx 1$ to $\approx 50 \%$, and there is a clear exponential inverse relationship with the mass particle content of the aerosol (Fig. 5a), with some evidence that the dissolution was under solubility control: a decrease from 100 to $40 \mathrm{mg} \mathrm{l}^{-1}$ in the particulate load content lead to an increase in solubility from $5 \%$ to $40 \%$. Whilst only a limited number of samples (30 over 55) were analysed for $\mathrm{Cd}$, due to technical problems, all of them show a solubility in the range from $70 \%$ to almost $100 \%$. In particular, only one SAH dust was available for this leaching experiment, and therefore the linear relationship shown in Fig $5 \mathrm{~b}$ is mainly related to anthropogenic-dominated aerosols. Our data, even if limited confirm the findings of Chester et al. (1993a) (19), who has already noted that $\mathrm{Cd}$ is relatively very soluble (> 80\%) from both the crust-rich and the urban rich aerosols.

In Fig. 6 we have plotted the $\%$ of dissolved lead with grain-size $<1 \mu \mathrm{m}$, the crustal Enrichment Factor $\left(\mathrm{EF}_{\text {crust }}\right)$ and $\mathrm{pH}$.

The solubility of $\mathrm{Pb}$ shows a good linear relationship with the finest grain-size fraction, $(\mathrm{r}=0.69, \mathrm{p}<0.001)$, with an evident increase in solubility with higher content of clay fraction $(<1 \mu \mathrm{m})$ of aerosol (Fig. 6a). The solubility of $\mathrm{Pb}$ appears also to be highly correlated $(r=0.70, p<0.001)$ to the EFcrust value (Fig. $6 b)$.

Chester et al. (1993a) (19) showed that $\mathrm{Pb}$ has higher $\mathrm{EF}_{\text {crust }}$ value and higher solubility in the urban-rich than in the crust-rich aerosol population. However they pointed out that in "mixed" aerosols re-scavenging by crustal material can affect Pb solubility, as a proportion of the metal initially released is taken back out of solution.

In Fig. 6c the percentage dissolution of lead as a function of $\mathrm{pH}$ is shown, and in the same figure we have also illustrated the theoretical $\mathrm{pH} /$ solubility curve studied by different authors, both in rain and in aerosol (Chester et al. 1993a (19); Lim et al. 1994 (17); Spokes and Jickells, 1996 (18). The relationship between Pb solubility and rainwater $\mathrm{pH}$ exhibits the classical $\mathrm{pH}$ adsorption edge, which is typical of adsorption/desorption processes at particulate-water interfaces. However, some authors note that the low solubility region is defined by a relatively small number of points, reflecting the few cases studied of rain with $\mathrm{pH}>6$ (Lim et al. 1994 (17); Spokes et al. 1994 (18). This observation is important, given that the rains normally contain variable amounts of particulate material and that particle concentrations, grain-size, and physical surface characteristics (scavenged clays or silicate mineral aerosol) may also be important parameters in adsorption models of trace metals in rain (Lim et al., 1994 (17). 
From Fig. 6c we can see that most of the samples plot inside the $\mathrm{pH} / \mathrm{solubility}$ "area" we have drawn with $\pm 10 \%$ of tolerance with respect to the 'classical' curve. Two groups of samples plot out this area. Few samples have lower than expected solubilites at $\mathrm{pH}$ value $\cong 5.5$. Those samples are 'mixed' aerosols (see e.g. Chester et al., 1993a (19) terminology), where some re-scavenging from crustal material is possible. In this case the crustal material eventually does not directly affect the solubility of the anthropogenic dominated part of the mixed aerosol, but behave as an external factor taking back from solution a proportion of the metal initially released. On the other hand, another group of samples plot out the adsorption curve, with higher solubilities as expected at $\mathrm{pH}$ values >6.5. A mineralogical inspection of the samples showed that those aerosols contains cerussite minerals, derived by sphalerite and galena old mine tailings, located at about 1$200 \mathrm{~km}$ away, that very rarely reach the sampling sites. Those samples were already described by Guerzoni et al., (1997) (2), and have average grain-size of 2-4 $\mu \mathrm{m}$. Those minerals are very often composed of carbonates, that can eventually leach out part of the lead, at pH values as high as 6.5-7.5 (Caboi et al., 1992) (27). After having discarded the cerussite-enriched samples the $\mathrm{pH} / \mathrm{solubility}$ correlation is quite good $(\mathrm{r}=-0.60$, $\mathrm{p}<0.001)$.

Therefore, in order to understand which were the most important parameters influencing the lead partitioning we have applied a multiple regression analyses to the reduced aerosol data-set, without the cerussite-enriched samples. The percentage of dissolved lead was taken as dependent variable, and we compared the relative importance of $\mathrm{EF}_{\text {crust }}$, grain-size $<1 \mu \mathrm{m}$, and $\mathrm{pH}$ in the variation of solubility. The results of this simple model showed that the variation in the dissolution of lead depends more from $\mathrm{EF}_{\text {crust }}$, and grain-size $(\sim 40 \%$ each) and less from $\mathrm{pH}(\sim 20 \%)$. This is evidently not a general conclusion, but is useful to highlight the multiple approach needed to understand the processes which alter metal solubility of aerosols.

\section{Metal fluxes at Sardinia}

Several authors have attempted to calculate metal fluxes from the atmosphere and have encountered several difficulties. Whilst the evaluation of the wet input, calculated from rainwater concentrations and rainfall amount is generally reliable, the estimation of dry deposition is more problematic. Despite the shortcomings in these estimates, Guieu et al (1997) (7) have made a compilation of available data on wet and dry fluxes around the Western MED Sea. Those authors have shown for many trace elements (e.g., Al, Pb, $\mathrm{Mn}, \mathrm{Fe}$ ) that the global flux from the atmosphere entirely dominates the total external input of pollution-derived elements, and that the atmosphere is also very important for elements of terrigenous origin such as $\mathrm{Al}$ and $\mathrm{Fe}$.

In this paper fluxes were calculated from rainfall and aerosol data listed in Tables 3 and 4. For precipitation samples the "wet" flux (e.g. in $\mathrm{mg} \mathrm{m}^{-2} \mathrm{yr}^{-1}$ ) was calculated by multiplying the metal concentration (in $\mu \mathrm{g} \mathrm{l}^{-1}$ ) by the amount of rain (litres) and dividing by the area of the sampler $\left(0.066 \mathrm{~m}^{-2}\right)$. For the aerosols, the "dry" flux (Fx) (e.g. mg m ${ }^{-2}$ $\mathrm{yr}^{-1}$ ) was calculated according to the following equation: $\mathrm{Fx}=\mathrm{c} * \mathrm{~V}_{\mathrm{d}}$, where $\underline{\mathrm{C}}$ is the metal concentration value in $\mathrm{ng} \mathrm{m}{ }^{-3}$ and $\underline{V}_{\mathrm{d}}$ is the deposition velocity in $\mathrm{cm} \mathrm{sec}^{-1}$. The deposition velocities used here were chosen within the range of literature values (Dulac 
et al., 1989 (11); Slinn and Slinn, 1980 (44); Migon et al., 1997 (14). The values were 2 $\mathrm{cm} \mathrm{sec}^{-1}$, for $\mathrm{Al}, \mathrm{Ca}, \mathrm{Fe}, \mathrm{Si}$, metals that derive principally from aerosols largely dominated by mineral particles, with a median grain-size of $2-10 \mu \mathrm{m}$. The selected deposition velocity for $\mathrm{Cd}$ and $\mathrm{Pb}$ was $0.2 \mathrm{~cm} \mathrm{sec}^{-1}$, because those are elements of predominantly anthropogenic origin, associated to finer grain-size $(<1 \mu \mathrm{m})$, and $1.0 \mathrm{~cm}$ $\mathrm{sec}^{-1}$ was chosen for $\mathrm{Cr}$, that appears to be related to both size fractions (Giusti et al., 1993) (43).

From aerosol and precipitation data collected at Sardinia we have calculated the dissolved and total fluxes separately, and the fraction of these fluxes that can be attributed to SAH dust.

As previously mentions, some problems arise in assessing the "dry" deposition of the anomalously enriched elements such as $\mathrm{Cd}$ and $\mathrm{Pb}$. We are aware that there is a fractionation from the aerosol to the dry deposition, which is largely particle-sized mediated. This fact is probably not so important in the estimate of the dry fluxes of nonenriched elements ( $\mathrm{Al}, \mathrm{Ca}, \mathrm{Fe}, \mathrm{Si}$ and $\mathrm{Cr}$ ). On the contrary, the dry fluxes of $\mathrm{Cd}$ and $\mathrm{Pb}$ may be considerably over-estimated, and our data can be seen as an upper limit, in case of SAH enriched episodes.

Model estimates yield a mineral dust deposition from North Africa of $170 \mathrm{Tg} \mathrm{yr}^{-1}$ to the Atlantic, $25 \mathrm{Tg} \mathrm{yr}^{-1}$ to the MED and $5 \mathrm{Tg} \mathrm{yr}^{-1}$ to the Caribbean (Prospero, 1996) (6). There is also an extremely large seasonal and inter-annual variability, in dust deposition and we might expect a comparable variability in consequent ocean effects.

Estimates $\left(\mathrm{mg} \mathrm{m}^{-2} \mathrm{yr}^{-1}\right)$ of the fluxes (dry+wet) of soluble and insoluble fractions and of the percentage that are due to Saharan dust contribution, for samples collected at Sardinia are listed in Table 5. On the basis of these data, the trace metals can be divided into three broad groups.

Group 1: which includes $\mathrm{Al}, \mathrm{Fe}$ and Si. For these trace metals the SAH fluxes over the total atmospheric fluxes exceeds $70 \%$, and the the insoluble fraction is prevalent.

Group 2: which includes $\mathrm{Ca}$ and $\mathrm{Cr}$. The contribution to the total deposition made by $\mathrm{SAH}$ is $\sim 60 \%$, and the dissolved fraction decreases from $\mathrm{Ca}(59 \%)$ to $\mathrm{Cr}(38 \%)$.

Group 3: which includes $\mathrm{Cd}$ and $\mathrm{Pb}$. The contribution to the total deposition made by $\mathrm{SAH}$ is $\sim 30 \%$, but the particulate/dissolved partitioning in the SAH and BKG varies between the two trace metals. For $\mathrm{Pb}$ the particulate fraction due to $\mathrm{SAH}$ is almost $40 \%$, whilst the dissolved fraction is less than $10 \%$. For $\mathrm{Cd}$ the dissolved fraction dominates the flux (64 vs $7 \mu \mathrm{g} \mathrm{m}^{-2} \mathrm{yr}^{-1}$ ) and the fraction due to SAH is almost one third of the total. 


\section{CONCLUSIONS}

1. Data on aerosol and precipitation collected at a remote site in Sardinia are presented. The partitioning of total atmospheric deposition between the soluble and the insoluble phases shows that $\mathrm{Al}, \mathrm{Si}, \mathrm{Fe}$ and $\mathrm{Pb}$ originating from the atmosphere are mostly (>90\%) in the insoluble form. For the other metals studied $(\mathrm{Ca}, \mathrm{Cd}, \mathrm{Cr})$, the dissolved fraction represents $50-90 \%$ of the total input.

2. In terms of its "chemical character", the Sardinia aerosol may be distinguished from those aerosols collected at the two sites of Blanes (Spain) and Cap Ferrat (France). In particular, the $\mathrm{BKG}$ aerosols show a 3 to 25-fold decrease in $\mathrm{EF}_{\text {crust }}$ values for $\mathrm{Cd}, \mathrm{Zn}$, $\mathrm{Pb}$, and $\mathrm{Cr}$ compared with coastal stations in the Western Mediterranean.

3. We have presented a series of novel experiments, carried out in closed system, which explored the role of particle concentrations in constraining metal solubilities. The principal conclusions are:

(i) at high particle concentrations the solubilitis of $\mathrm{Al}, \mathrm{Fe}, \mathrm{Pb}$ and $\mathrm{Cd}$ decrease;

(ii) $\mathrm{Al}$ and $\mathrm{Pb}$ solubilities decrease with increasing $\mathrm{pH}$ values;

(iii) the solubility of $\mathrm{Pb}$ increase with increasing $\mathrm{EF}$ values and decreasing particle size

4. Estimates of the fluxes (dry +wet) of metals show that $\cong 30 \%$ for $\mathrm{Cd}$ and $\mathrm{Pb}$, to more than $80 \%$ for $\mathrm{Fe}$ and $\mathrm{Al}$ are due to Saharan contribution.

\section{Acknowledgements}

This is the Istituto di Geologia Marina-Consiglio Nazionale delle Ricerche scientific contribution $\mathrm{N}^{\circ} 1135$. This work was partially supported by the Commission of the European Communities/Sciences and Technology Environmental Programme Contract STEP-CT N-080-0080, and by World Meteorological Organisation Contract 20.028/A/CNS. We thank the Italian Meteorological Service, at the Capo Carbonara station, for the use of its site and meteorological data during sampling. We thank also C. Ori for help in data management, G. Cesari for sampling help, and G. Zini for drawings. The authors would like to thank Ms. G. Walton for revision of the English text. 


\section{REFERENCES}

1. R. A. Duce, P. S. Liss, J. T. Merrill, E. L. Atlas, P. Baut-Menard, B. B. Hicks, J. M. Miller, J. M. Prospero, R. Arimoto, T. M. Church, W. Ellis, J. N. Galloway, L. Hansen, T. D. Jickells, A. H. Knap, K. H. Reinhardt, B. Schneider, A. Soudine, J. J. Tokos, S. Tsunogai, R. Wollast and M. Zhou, The atmospheric input of trace species to the world ocean, Global Biogeochem. Cycl. 5, 193-259 (1991).

2. S. Guerzoni, E. Molinaroli and R. Chester, SAH dust inputs to the W. Mediterranean Sea: depositional patterns, geochemistry and sedimentological implications, Deep-Sea Res. II 44, (3-4), 631-654 (1997).

3. M. D. Loÿe-Pilot and J. M. Martin, SAH dust input to the Western Mediterranean: an eleven years record in Corsica, In The Impact of Desert Dust Across the Mediterranean (Edited by S. Guerzoni and R. Chester), 191-199. Kluwer Acad. Publisher, (1996).

4. G. Bergametti, L. Gomes, E. Remoudaki, M. Desbois, D. Martin and P. BuatMenard, Present-day transport and deposition patterns of African dusts to the North-Western Mediterranean, In Modern and Past Patterns of Global Atmospheric Transport (Edited by M. Leinen and M. Sarnthein), 227-252. Kluwer, Dordrecht, (1989).

5. G. A. D'Almeida, A model for SAH dust transport, Journal of Climate and Applied Meteorology 25, 903-916 (1986).

6. J. M. Prospero, SAH dust transport over the North Atlantic ocean and MED: an overview, In The Impact of Desert Dust Across the Mediterranean. (Edited by S. Guerzoni and R.Chester), 133-151. Kluwer, The Netherlands (1996).

7. C. Guieu, R. Chester, M. Nimmo, J. M. Martin, S. Guerzoni, E. Nicolas, J. Mateu and S. Keyse, Atmospheric input of dissolved and particulate metals in the NW Mediterranean, Deep-Sea Research II 44, N. 3-4, 655-674 (1997).

8. P. Rossini and S. Guerzoni, Carichi di metalli al mare Adriatico settentrionale attraverso le deposizioni atmosferiche. PRISMA Phase I Workshop, Bologna, Italy (1996).

9. R. A. Duce and N. W. Tindale, Atmospheric transport of iron and its deposition in the ocean, Limnology and Oceanography 36, 1715-1726 (1991).

10. R. W. Young, K. L. Carder, P. R. Betzer, D. K. Costello, R. A. Duce, G. R. Ditullio, N. W. Tindale, E. A. Laws, M. Uematsu, J. T. Merril and R. A. Feely, Atmospheric iron inputs and primary productivity: phytoplankton responses in the North Pacific, Global Biogeochemical Cycles 5, 119-134 (1991).

11. F. Dulac, P. Buat-Menard, U. Ezat, S. Melki and G. Bergametti, Atmospheric input of trace metals to the Western MED Sea: uncertainities in modelling dry deposition from cascade impactor data, Tellus 41B, 362-378 (1989).

12. E. Remoudaki, G. Bergametti and R. Losno, On the dynamic of the atmospheric input of $\mathrm{Cu}$ and $\mathrm{Mn}$ into the western Mediterranean Sea, Atmospheric Environment 25A, 733-744 (1991).

13. C. Migon, J. Morelli, E. Nicolas, and G. Copin-Montégut, Evaluation of total atmospheric deposition of $\mathrm{Pb}, \mathrm{Cd}, \mathrm{Cu}$ and $\mathrm{Zn}$ to the Ligurian Sea, Science of Total Environment 105, 135-148 (1991). 
14. C. Migon, B. Journel and E. Nicolas, Measurement of trace metal wet, dry and total atmospheric fluxes over the Ligurian Sea, Atmospheric Environment 31, 889-896 (1997).

15. T. D. Jickells, Atmospheric inputs of metals and nutrients to the oceans: their magnitude and effects, Marine Chemistry 48, 199-214 (1995).

16. R. Losno, J. L. Colin, N. Lebris, G. Bergametti, T. Jickells and B. Lim, Solubility of aluminium and iron in rainwater and molten snow, J. Atmos. Chem. 17, 29-43 (1993).

17. B. Lim, T. D. Jickells, J. L. Colin and R. Losno, Solubilities of $\mathrm{Al}, \mathrm{Pb}, \mathrm{Cu}$, and $\mathrm{Zn}$ in rain sampled in the marine environment over the North Atlantic ocean and Mediterranean Sea, Global Biogeochemical Cycles 8, 349-362 (1994).

18. L. J. Spokes, T. D. Jickells and B. Lim, Solubilisation of aerosol trace metals by cloud processing: a laboratory study, Geochimica et Cosmochimica Acta 58, n.15, 3281-3287 (1994).

19. R. Chester, M. Nimmo, M. Alarcon, C. Saydam, K. J. T. Murphy, G. S. Sanders and P. Corcoran, Defining the chemical character of aerosols from the atmosphere of the Mediterranean Sea and surroundings regions, Oceanologica Acta 16 (3), 231245 (1993a).

20. P. J. Stathan and R. Chester, Dissolution of manganese from marine atmospheric particulates in seawater and rainwater, Geochim. Cosmochim, Acta. 52, 2433-2437 (1988).

21. C. Guieu, R. Duce and R. Arimoto, Dissolved input of manganese to the ocean: aerosol source, J. Geophys. Res. 99, D9, 18, 789-18, 800 (1994).

22. S. Guerzoni, W. Landuzzi, R. Lenaz, G. Quarantotto, G. Rampazzo, E. Molinaroli, C. Turetta, F. Visin, G. Cesari and S. Cristini, Fluxes of soluble and insoluble metals and nutrients from the atmosphere to the Central Mediterranean Sea, Water Poll. Reas. Rep. 30, 438-493 (1993).

23. E. Molinaroli, S. Guerzoni and G. Rampazzo, Contribution of SAH dust to the Central Mediterranean Basin, In Processes Controlling the Composition of Clastic Sediments (Edited by M. Johnsson and A. Basu), SP 284, 303-312, Geol. Soc. America (1993).

24. S. Guerzoni, G. Quarantotto, E. Molinaroli and G. Rampazzo, More data on source signature and seasonal fluxes to the Central Mediterranean Sea of aerosol dust originated in desert area, Water Pollution Research Report 32, 267-274 (1995).

25. J. M. Harris, The GMCC atmospheric trajectory program, ERL ARL-116, NOAA Technical memorandum, NGAA, Boulder, Colorado, (1982).

26. E. Molinaroli, Mineralogical characterisation of SAH dust with a view to its final destination in Mediterranean sediments, In The Impact of Desert Dust Across the Mediterranean (edited by S. Guerzoni and R. Chester), 153-162. Kluwer Acad. Publisher (1996).

27. R. Caboi, A. Cidu, S. Cristini, L. Fanfani and P. Zuddas, Influence of SAH dust and marine spray on the chemical composition of rain in Sardinia. 7th Int. Symposium on Water-Rock Interaction, 14-18 July, Park City, Utah USA (1992).

28. O. Le Bolloch and S. Guerzoni, Acid and alkaline deposition in precipitation on the Western coast of Sardinia, Central Mediterranean $\left(40^{\circ} \mathrm{N}, 8^{\circ} \mathrm{E}\right)$, Water Air and Soil Pollution 85 (4), 2155-2160 (1995). 
29. M. D. Loÿe-Pilot, J. M. Martin and J. Morelli J., Influence of SAH dust on the rain acidity and atmospheric input to the Mediterranean, Nature 321, 427-428 (1986).

30. S. Glavas, A wet-only precipitation study in a Mediterranean site, Patras, Greece, Atmospheric Environment 22, 1505-1507 (1988).

31. Roda, J. Bellot, A. Avila, A. Escarre', J. Pinol and J. Terradas, SAH dust and the atmospheric inputs of elements and alkalinity to Mediterranean ecosystems, Water, Air and Soil Pollution 66, 277-288 (1993).

32. S. R. Taylor, Abundance of chemical elements in the continental crust: a new table, Geochimica and Cosmochimica Acta 28, 1237-1285 (1964).

33. L. J. Spokes and T. D. Jickells, Factors controlling the solubility of aerosol trace metals in the atmosphere and on mixing into seawater, Aquatic Geochemistry 1(4), 355-374 (1996).

34. K. A. Rahn, The chemical composition of the atmospheric aerosol, Tech. Rep., Graduate School of Oceanography, University of Rhode Island, Kingston, R.I. (1976).

35. J. M. Prospero, Arid regions as sources of mineral aerosols in the marine atmosphere, Geological Society of America SP 186, 71-85 (1981).

36. Chester, K J. T. Murphy, F. J. Lin, A. S. Berry, G. A. Bradshaw and P. A. Corcoran, Factors controlling the solubilities of trace metals from non-remote aerosols deposited to the sea surface by the 'dry' deposition mode, Mar. Chem. 42, 107-126 (1993b).

37. H. B. Maring and R. A. Duce, The impact of atmospheric aerosols on trace metal chemistry in open surface seawater 1. Aluminium, Earth Planet. Sci. Lett. 84, 381392 (1989).

38. E. Wieland and W. Stumm, Dissolution kinetics of kaolinite in acidic solutions at $25^{\circ} \mathrm{C}$, Geochimica et Cosmochimica Acta 56, 3339-3355 (1992).

39. W. Stumm, Chemistry of the solid-water interface: processes at the mineral-water and particle-water interface in natural systems. John Wiley, New York (1992).

40. F. M. M. Morel and P. M. Gschwend, The role of colloids in the partitioning of solutes in natural waters, In Aquatic Surface Chemistry (edited by W. Stumm), 405-422, John Wiley, New York, (1987).

41. D.J. Hydes and K. Kremling, Patchiness in dissolved metals (Al, Cd, Co, Cu, Mn, $\mathrm{Ni}$ ) in North Sea surface waters: seasonal differences and influence of suspended sediment, Continental Shelf Research 13, 1083-1101 (1993).

42. B.D. Honeyman and P.H. Santchi, Metals in aquatic systems, Environ. Sci,. Technol. 22, 862-871 (1988)

43. L. Giusti, Y.-L. Yang, C. N. Hewitt, J. Hamilton-Taylor and W. Davison, The solubility and partitioning of atmospherically derived trace metals in artificial and natural waters: a review, Atmospheric Environment 27A, 1567-1578 (1993). 
Tab. 1- Particulate load and grain-size characteristic of Saharan and Background aerosols (from Guerzoni et al., 1993 (22) ).

\begin{tabular}{lccc}
\hline & & Saharan & Background \\
\hline $\begin{array}{l}\text { Particulate } \\
\text { load “ }\end{array}$ & $\mu \mathrm{g} \mathrm{m}^{-3}$ soluble & 25 & 16 \\
\multicolumn{1}{c}{ “ } & $\mu \mathrm{g} \mathrm{m}^{-3}$ insoluble & 26 & 4 \\
\hline$<1 \mu \mathrm{m}$ & $\%$ & 8 & 24 \\
$1-2 \mu \mathrm{m}$ & $\%$ & 21 & 20 \\
$2-8 \mu \mathrm{m}$ & $\%$ & 40 & 22 \\
$8-32 \mu \mathrm{m}$ & $\%$ & 27 & 27 \\
$>32 \mu \mathrm{m}$ & $\%$ & 4 & 7 \\
\hline
\end{tabular}

Tab. 2 - Concentration of particulate load in air and rain at Sardinia (from Guerzoni et al, 1997 (2))

\begin{tabular}{lcc}
\hline & air $\left(\mu \mathrm{g} \mathrm{m}^{-3}\right)$ & rain $\left(\mathrm{mg} \mathrm{l}^{-1}\right)$ \\
\hline Background & $1-3$ & $0.1-10$ \\
Desert-enriched & 20 & $10-50$ \\
Saharan outbreaks & 44 & $50-500$ \\
Maximum recorded & 110 & 510 \\
\hline
\end{tabular}


Tab. 3 - Relevant data of the aerosol collected at Sardinia. The data are divided in two groups: Saharan, mainly desertenriched aerosol, and Background (mainly anthropogenic-maritime enriched aerosol). Mean total concentrations, enrichment factors $\left(\mathrm{EF}_{\text {crust }}\right.$, see text for explanation) and the percentage of dissolved fraction are indicated,on Saharan and Background samples respectively.

\begin{tabular}{l|ccc|ccc}
\hline & \multicolumn{3}{|c|}{ Saharan $(\mathrm{n}=7)$} & \multicolumn{3}{c}{ Background $(\mathrm{n}=48)$} \\
\hline Element & $\begin{array}{c}\text { Conc. } \\
\left(\mathrm{ng} \mathrm{m}^{-3}\right)\end{array}$ & $\mathrm{EF}_{\text {crust }}$ & $\begin{array}{c}\text { Sol. } \\
(\%)\end{array}$ & $\begin{array}{c}\text { Conc. } \\
\mathrm{ng} \mathrm{m}^{-3}\end{array}$ & $\mathrm{EF}_{\text {crust }}$ & $\begin{array}{c}\text { Sol. } \\
(\%)\end{array}$ \\
\hline $\mathrm{Al}$ & 2929 & --- & $(1)$ & 210 & --- & $(6)$ \\
$\mathrm{Ca}$ & 3364 & 3 & $(81)$ & 629 & 15 & $(96)$ \\
$\mathrm{Fe}$ & 1138 & 1.7 & $(0.2)$ & 84 & 8.3 & $(10)$ \\
$\mathrm{Si}$ & 5875 & 0.8 & $(1)$ & 609 & 1.3 & $(6)$ \\
$\mathrm{Na}$ & 5066 & 11 & $(87)$ & 4084 & 268 & $(95)$ \\
$\mathrm{K}$ & 753 & 1.5 & $(50)$ & 280 & 23 & $(83)$ \\
$\mathrm{Mg}$ & 1271 & 2 & $(90)$ & 615 & 30 & $(95)$ \\
$\mathrm{Cd}$ & 0.08 & 12 & $(57)$ & 0.17 & 80 & $(88)$ \\
$\mathrm{Cr}$ & 3.3 & 1.1 & $(20)$ & 0.5 & 3.3 & $(52)$ \\
$\mathrm{Pb}$ & 25.3 & 66 & $(9)$ & 11.7 & 550 & $(20)$ \\
\hline
\end{tabular}

Tab.4 - Mean total concentration $\left(\mu g \mathrm{l}^{-1}\right)$ and enrichment factors $\left(\mathrm{EF}_{\text {crust }}\right.$, see text for explanation) of major elements and trace metals for rainwater, divided in Saharan and Background. In brackets the percentage of dissolved fraction. (*) Particulate load is in $\mathrm{mg} \mathrm{l}^{-1}$.

\begin{tabular}{l|ccc|ccc}
\hline Element & \multicolumn{3}{|c|}{ Saharan $(\mathrm{n}=10)$} & \multicolumn{3}{c}{ Background $(\mathrm{n}=23)$} \\
\hline & Conc. $\left(\mu \mathrm{g} \mathrm{l}^{-1}\right)$ & $\mathrm{EF}_{\text {crust }}$ & Sol. $(\%)$ & Conc. $\left(\mu \mathrm{g} \mathrm{l}^{-1}\right)$ & $\mathrm{EF}_{\text {crust }}$ & Sol. $(\%)$ \\
\hline $\mathrm{Al}$ & 2780 & --- & 0.4 & 228 & --- & 6 \\
$\mathrm{Ca}$ & 6530 & 4 & 92 & 1430 & 11 & 98 \\
$\mathrm{Fe}$ & 1523 & 0.8 & 0.8 & 136 & 0.9 & 10 \\
$\mathrm{Si}$ & 7894 & 0.8 & 5 & 1021 & 12 & 32 \\
$\mathrm{Na}$ & 15890 & 21 & 99 & 7725 & 125 & 99 \\
$\mathrm{~K}$ & 909 & 1.3 & 39 & 331 & 5.8 & 59 \\
$\mathrm{Mg}$ & 860 & 0.9 & 52 & 226 & 2.9 & 70 \\
$\mathrm{Cd}$ & 0.15 & 22 & 87 & 0.10 & 183 & 90 \\
$\mathrm{Cr}$ & 0.91 & 0.2 & 49 & 0.48 & 16 & 63 \\
$\mathrm{~Pb}$ & 1.9 & 3 & 32 & 13.9 & 281 & 77 \\
$\mathrm{Particulate} \mathrm{load} *$ & 93 & & 59 & 67 & & 94 \\
\hline
\end{tabular}


Tab. 5 - Estimates $\left(\mathrm{mg} \mathrm{m}^{-2} \mathrm{yr}^{-1}\right)$ of the fluxes (dry+wet) of soluble and insoluble fractions and of the percentage that are due to Saharan dust contribution for samples collected at Sardinia.

\begin{tabular}{l|rrr|rrr|rrr}
\hline Element & Insoluble & ins-Sah & \%ins-Sah & Soluble & sol-Sah & \%sol-Sah & Total & tot-Sah & \%tot-Sah \\
\hline & & & & & & & & & \\
$\mathrm{Al}$ & 891 & 734 & 0.82 & 16 & 6 & 0.36 & 907 & 739 & 0.82 \\
$\mathrm{Ca}$ & 175 & 154 & 0.88 & 1734 & 1029 & 0.59 & 1909 & 1183 & 0.62 \\
$\mathrm{Fe}$ & 406 & 330 & 0.81 & 10 & 2 & 0.18 & 416 & 332 & 0.80 \\
$\mathrm{Si}$ & 2143 & 1666 & 0.78 & 166 & 49 & 0.30 & 2309 & 1715 & 0.74 \\
$\mathrm{Cd}$ & 0.005 & 0.002 & 0.45 & 0.050 & 0.014 & 0.29 & 0.05 & 0.016 & 0.30 \\
$\mathrm{Cr}$ & 0.36 & 0.26 & 0.72 & 0.26 & 0.10 & 0.38 & 0.62 & 0.36 & 0.58 \\
$\mathrm{~Pb}$ & 1.19 & 0.49 & 0.41 & 1.10 & 0.10 & 0.09 & 2.29 & 0.59 & 0.26 \\
\hline
\end{tabular}




\section{FIGURE CAPTIONS}

Fig.1 The Mediterranean basin with the location of sampling station.

Fig. 2- Variation of aerosol lead (above, $\mathrm{ng} \mathrm{m}^{-3}$ ) and mineral suspended particulate (below, $\mu \mathrm{g} \mathrm{m}^{-3}$ ) concentrations over a seven-months period (Oct '90-Apr '91) at a remote site in Sardinia (data from Guerzoni et al., 1997), illustrating the large-scale short-term variability.

Fig. 3 - EF diagrams for $\mathrm{Fe}, \mathrm{Zn}$ and $\mathrm{Pb}$ for the Sardinia particulate aerosol (A) superimposed on data from two mainland coastal stations: Blanes (+) and Cap Ferrat (o) (from ref. 19).

Fig. 4 -Percentage dissolution of aluminium (above) and iron (below) in aerosols collected at Sardinia station as a function of particulate load. Filled dots represent SAH samples.

Fig. 4c Percentage dissolution of aluminium in aerosols collected at Sardinia station as a function of $\mathrm{pH}$

Fig. 5 - Percentage dissolution of lead (above), cadmium (below) in aerosols collected at Sardinia station as a function of particulate load. Filled dots represent SAH samples.

Fig. 6 - Percentage dissolution of lead as a function of grain-size fraction $<1 \mu \mathrm{m}$ (above), of enrichment factor (centre) and $\mathrm{pH}$ (below) in aerosols collected at Sardinia. Oper squares are the cerussite-enriched samples, and filled triangles are mixed aerosols (see text for explanations). 


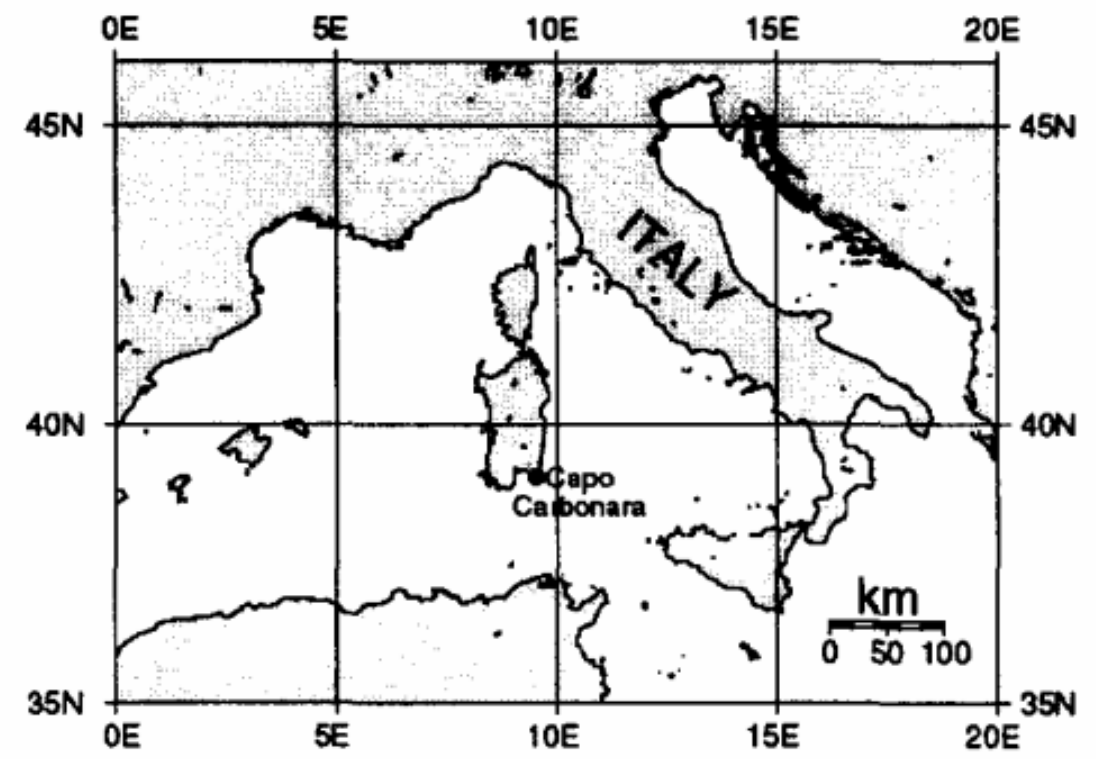

FIG. 1
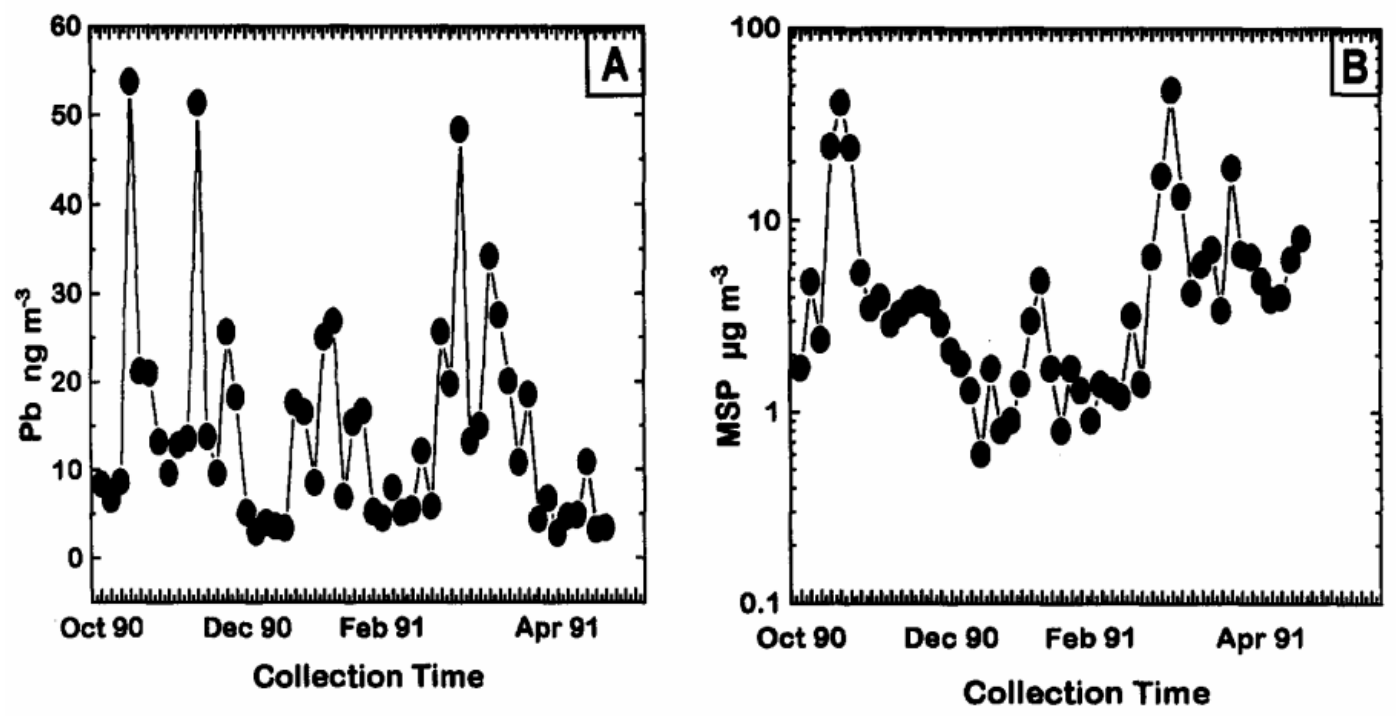

FIG: 2 

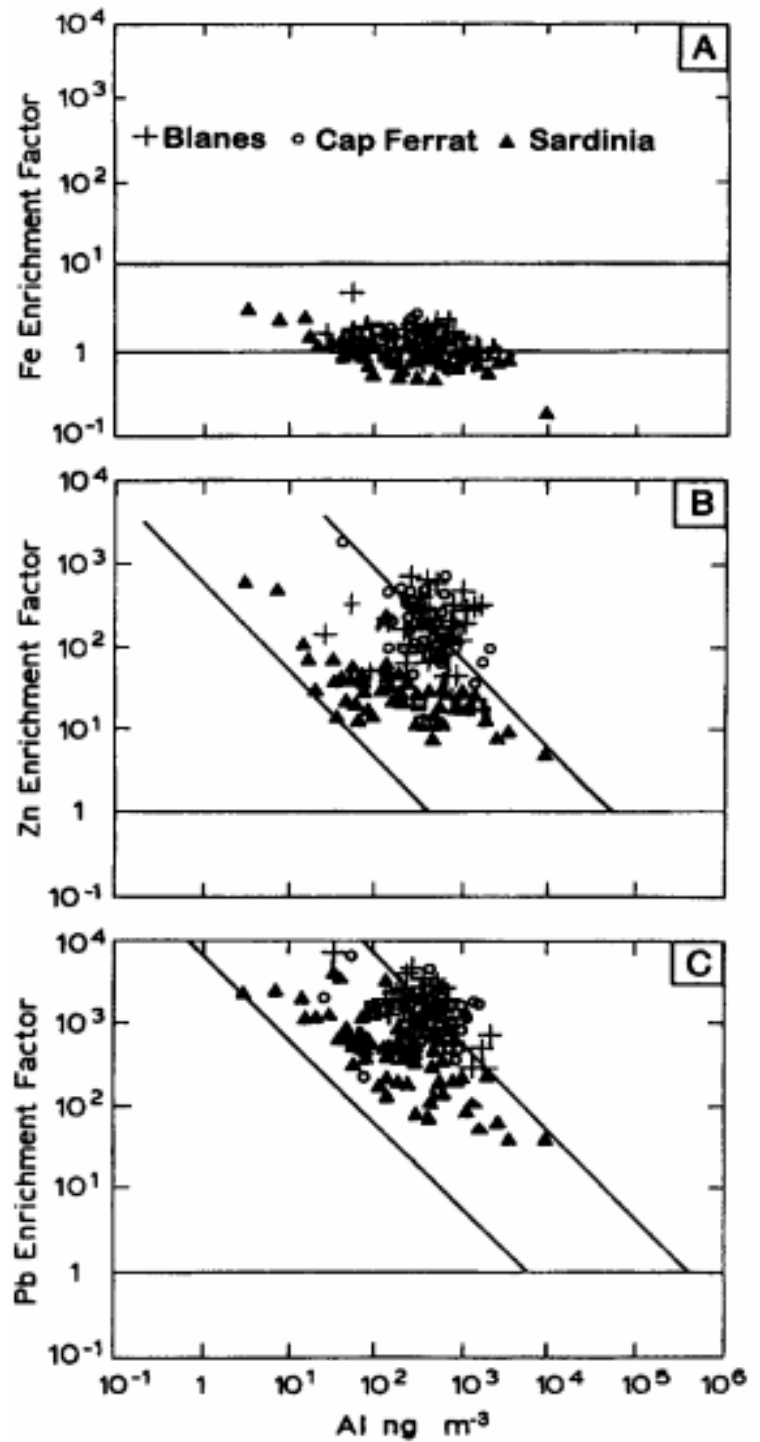

FIG: 3 

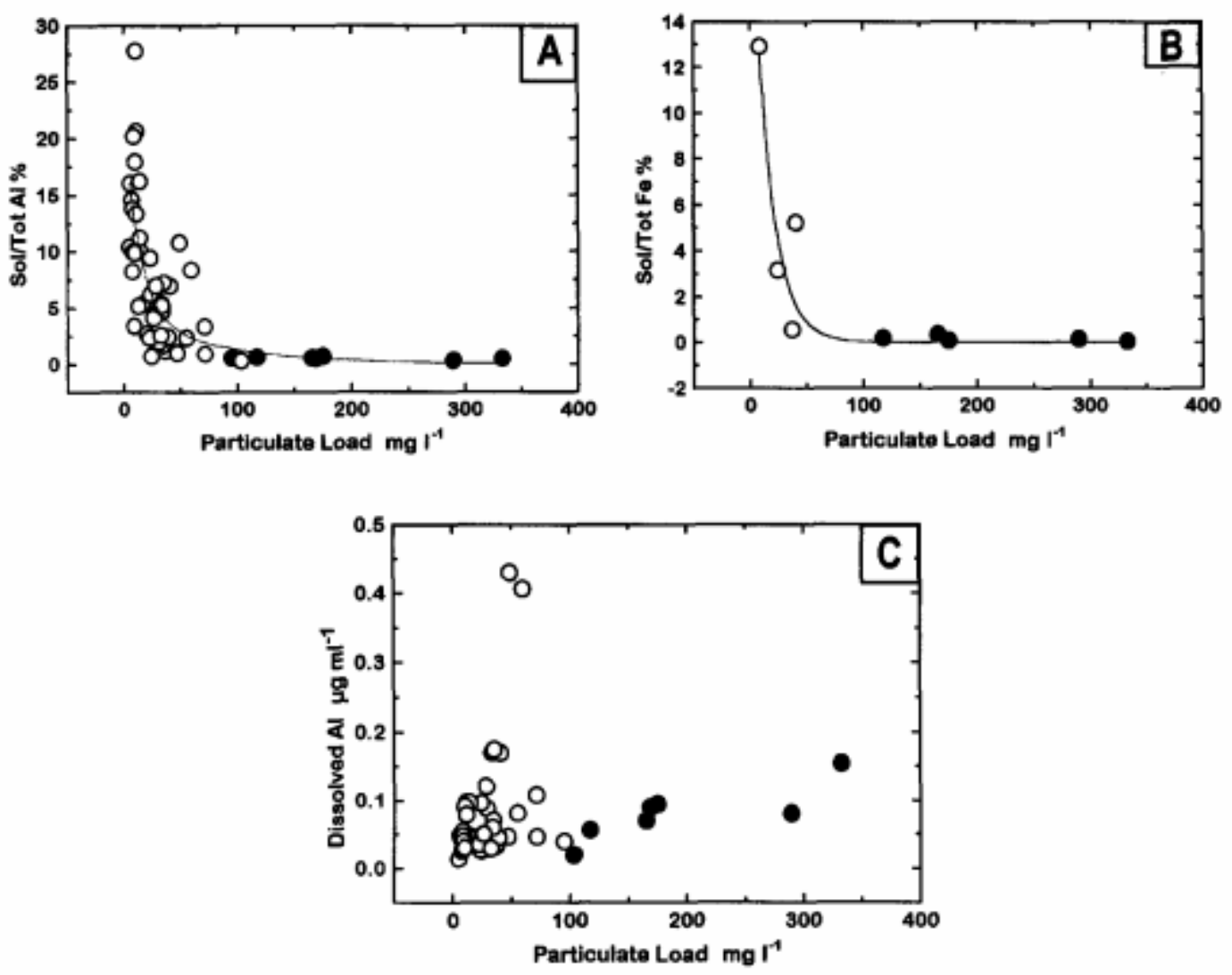

FIG: 4
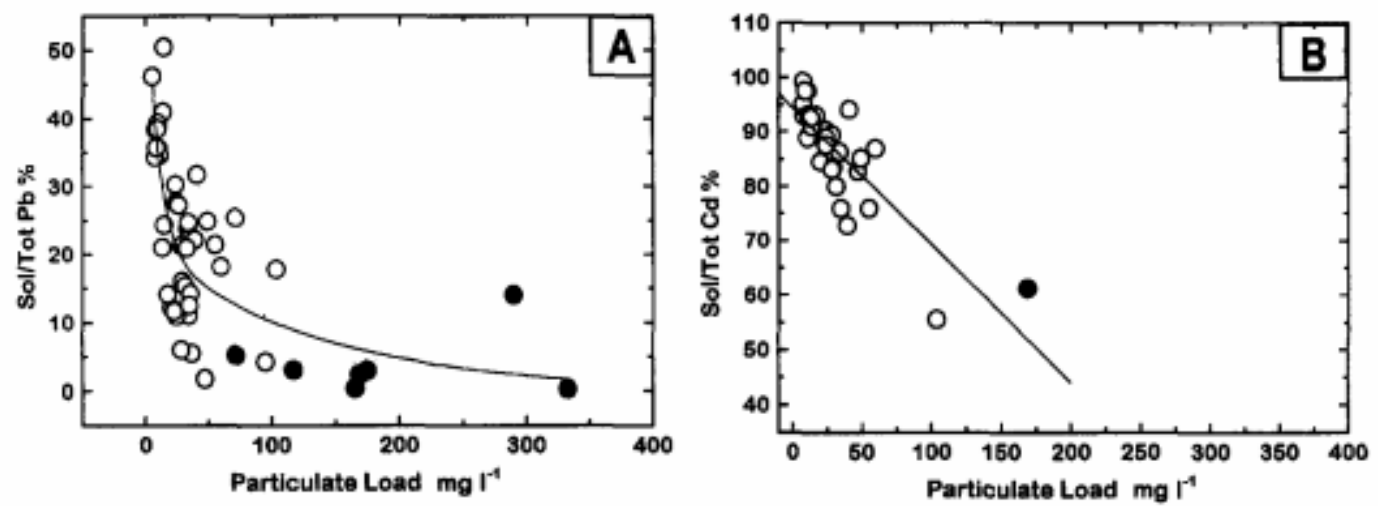

FIG: 5 

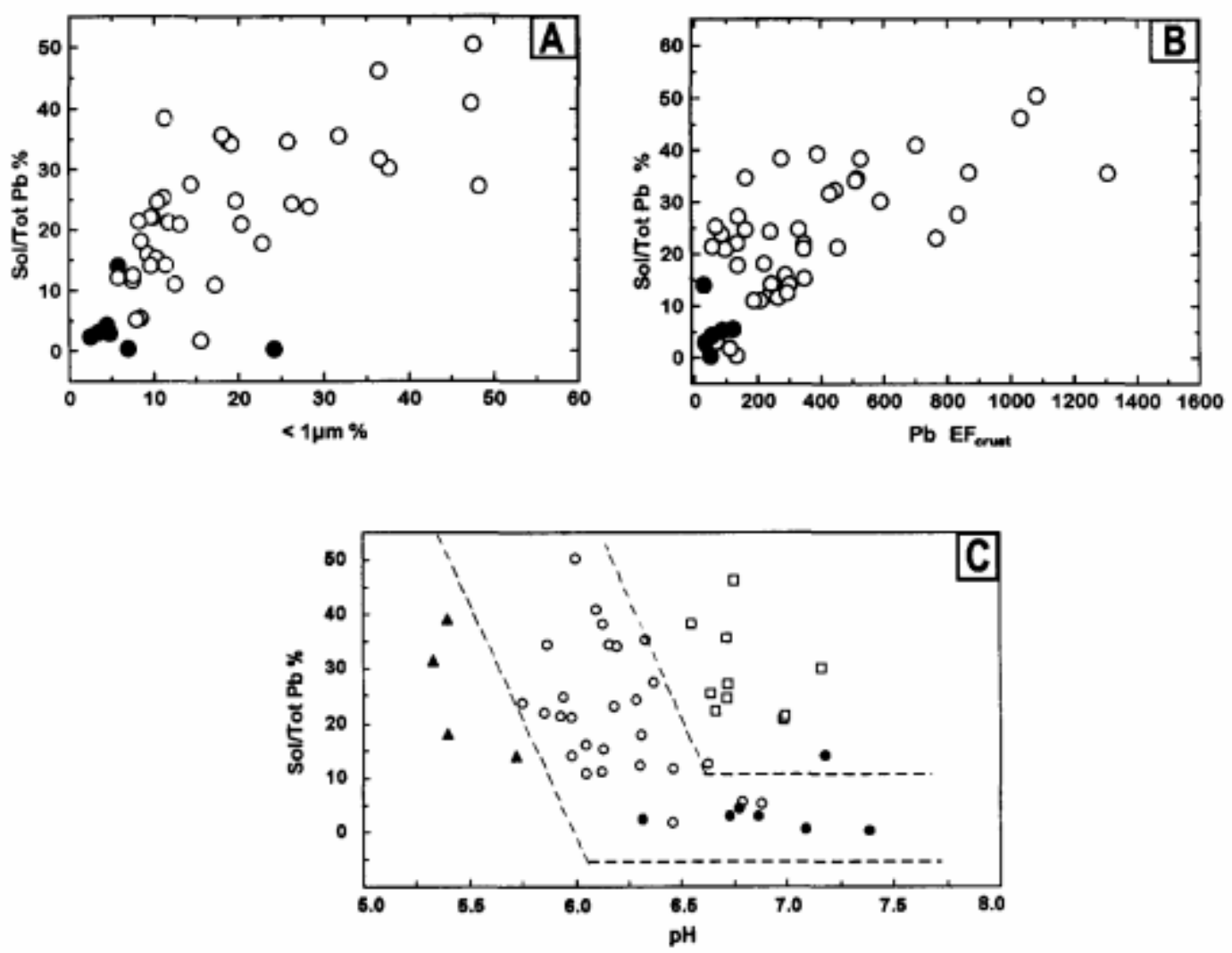

FIG. 6 